Bangladesh J. Bot. 37(1): 15-19, 2008 (June)

\title{
SCANNING ELECTRON MICROSCOPY OF FLORAL INITIATION AND DEVELOPMENTAL STAGES IN SWEET CHERRY (PRUNUS AVIUM) UNDER WATER DEFICITS
}

\author{
HAKAN ENGIN \\ Department of Horticulture, Faculty of Agriculture, Çanakkale Onsekiz Mart University, \\ TR-17020 Çanakkale, Turkey
}

Key words: Floral initiation, Bud differentiation, Irrigation, Prunus avium, Sweet cherry

\begin{abstract}
The influence of different irrigation conditions on flower bud development of the sweet cherry cv. '0900 Ziraat' was studied using scanning electron microscopy. Flower bud development was compared in three irrigation treatments. Control trees $\left(\mathrm{I}_{100}\right)$ were irrigated at approximately $100 \%$ ET. Stress treatments received $50 \%\left(\mathrm{I}_{50}\right)$ and $20 \%\left(\mathrm{I}_{20}\right)$ of the water applied to the control. The rate of flower bud initiation at the stage of differentiation of sepal, petal, stamen and pistil primordia was considerably slower at $\mathrm{I}_{20}$ as compared to the more irrigated treatments. Also, when water was not provided in the next year, flower bud initiation and differentiation was delayed. These results suggested that the lower the irrigation, the slower the progression of flower differentiation.
\end{abstract}

\section{Introduction}

The most popular Turkish cherry cultivar is '0900 Ziraat' gives poor yield, specially when it is grown in the western Turkey, where the post harvest period is very long and includes the hottest and driest months of the year. Therefore, water deprivation during this period might be the expected cause of variation in the progression of flower differentiation in cherry.

Flower bud initiation is important in fruit tree cultivation due to the dependence of fruit formation on this character. Floral induction is thought to be the outcome of a biochemical signal that causes cells within a bud to begin programmatic transitions from a vegetative to a floral stage (Faust 1989). Westwood (1993) suggested that floral initiation in sweet cherries occurs after harvest. Sepals, petals and stamens differentiate sequentially, and pistil primordia are also initiated. Floral induction, initiation and differentiation can be important for developing management strategies to enhance flowering and which ultimately regulate fruit crop loads.

In this study, we investigated the effect of water stress on progression of flower differentiation under field conditions using scanning electron microscope (SEM).

\section{Materials and Methods}

A block of 14-year-old '0900 Ziraat' cherry trees, the most popular cultivar in Turkey on account of its excellent fruit quality, located at the orchard near University of Ege, Izmir was used for this study. Tree spacing was $5 \times 5 \mathrm{~m}$. Soil type was a fine sandy loam. Five trees were used per treatment.

Each year before harvest, all trees received the same standard practice of furrow irrigation at every two weeks. Irrigation treatments were started after harvest in the middle of June and trees were irrigated at every ten days. The control trees received optimum irrigation to atttain approximately 100\% evapotranspiration $\left(\mathrm{I}_{100}\right)$ during postharvest season of both 2004 and 2005 and considered as moderate water stress treatment $\left(\mathrm{I}_{50}\right)$ received $50 \%$ of the water applied to the control. The severe water stress $\left(\mathrm{I}_{20}\right)$ received $20 \%$ of the water applied to the control.

Twenty buds, uniform in size and vigor, were collected at every ten days from five trees with effect from July 21 to September 19 in both 2004 and 2005. The samples were fixed and stored in

E-mail. hakanengin@comu.edu.tr 
a solution of FAA (McLaughlin and Greene 1991). Ten buds from each sample were dissected using an Olympus SZ 60 stereomicroscope before processing for SEM. Buds were rinsed twice (10 min each) in $50 \%$ ethanol and were kept in 50\% ethanol during dissection to prevent desiccation. Later the samples were dehydrated in an ethanol series (50, 70 and $95 \%$ for 10 min each) then twice in $100 \%$ for 10 min (Guimond et al. 1998). The samples were dried with a critical-point dryer and stored in a desiccator over anhydrous $\mathrm{CaSO}_{4}$. The samples were mounted on stainless-steel stubs with carbon tape before being gold coated with a sputter coater (Polaron SC 502). The samples were examined with a scanning electron microscope (Jeol ISM 5200). The photographs of morphological differentiation of the samples were taken with a camera attached to SEM. The morphological changes of flower primordia were observed by SEM and the developmental stage of the flower buds was classified as described by Kappel et al. (1990) for sweet cherry.

\section{Results and Discussion}

The use of SEM revealed the developmental stages of the flower buds in '0900 Ziraat' sweet cherry (Fig.1). The first sign of floral initiation occurs when the meristematic apex of the bud becomes a dome-like in shape (Fig.1A), in which floral organs were destined to differentiate laterally.

After bud differentiation, floral primordia developed in the order of flower primordia (Fig.1B), sepal (Fig.1C), petal (Fig.1D), stamen and pistil, and these organs obtained their normal forms by mid-September (Fig.1E).

Results of flower bud development within different irrigation treatments are shown in Tables 1 and 2. At the beginning of the irrigation treatments, there were no significant differences on the progression of flower bud formation in 2004.

The first samples were obtained at the end of July when $50 \%$ of the flower buds in treatment $\mathrm{I}_{100}$ were in the stage of stamen primordia. In the treatment $\mathrm{I}_{50}, 69 \%$ of the buds were in the stage of petal primordia. In the treatment $I_{20}$ (the trees most severely stressed), most of the flower buds were found in the stage of petal primordia. In the flower buds collected in the middle of August, the most advanced developmental stage was observed in the treatment $\mathrm{I}_{100}$, with $72 \%$ of the buds in the stage of pistil primordia. In the other two treatments, $83 \%$ of the flower buds were in the stage of stamen primordia, with $9 \%$ in the stage of pistil primordia in treatment $\mathrm{I}_{50}$ and $7 \%$ in the stage of stamen primordia in treatment $\mathrm{I}_{20}$, maintaining the delay observed previously. Most of the samples collected at the end of August reached the stage of stamen primordia of their development, in all the treatments. Finally, 83 - $97 \%$ of the samples collected in the middle of September were found in the stage of pistil primordia, in all the treatments (Table 1).

At the onset of the treatments in 2005, the flower buds had already formed sepal, petal and stamen primordia, but not pistil primordia (Table 2). At $\mathrm{I}_{100}$, pistil differentiation progressed quickly and about $43 \%$ of the buds had formed pistil primordia by August 20.

The rate of pistil formation was considerably slower at the severe stress treatment $\left(I_{20}\right)$. At $I_{20}$, only 3\% of the buds having differentiated pistils on August 30 in 2005.

Results clearly showed that irrigation during flower bud formation markedly affected the progression of floral differentiation in '0900 Ziraat' sweet cherry. It was observed that water stress delayed the differentiation of pistil primordia, thereby prolonging the period during which floral primordia could be subjected to further water stress.

When the effect of different periods of drought stress on the development of flower buds of the apricot cv. Guillermo was studied (Alburguerque et al. 2003), it was found that with the longer stress period the differentiation time was delayed and their development was slowed. Engin (2006) also found that the peach flower bud from irrigated trees reached more advanced stages sooner 
than buds from non-irrigated plots. Data obtained during this study show that, when there was a lack of water in one treatment, the development of flower buds was slowed. In addition, when water was not provided again in the next year, flower bud initiation was also delayed.

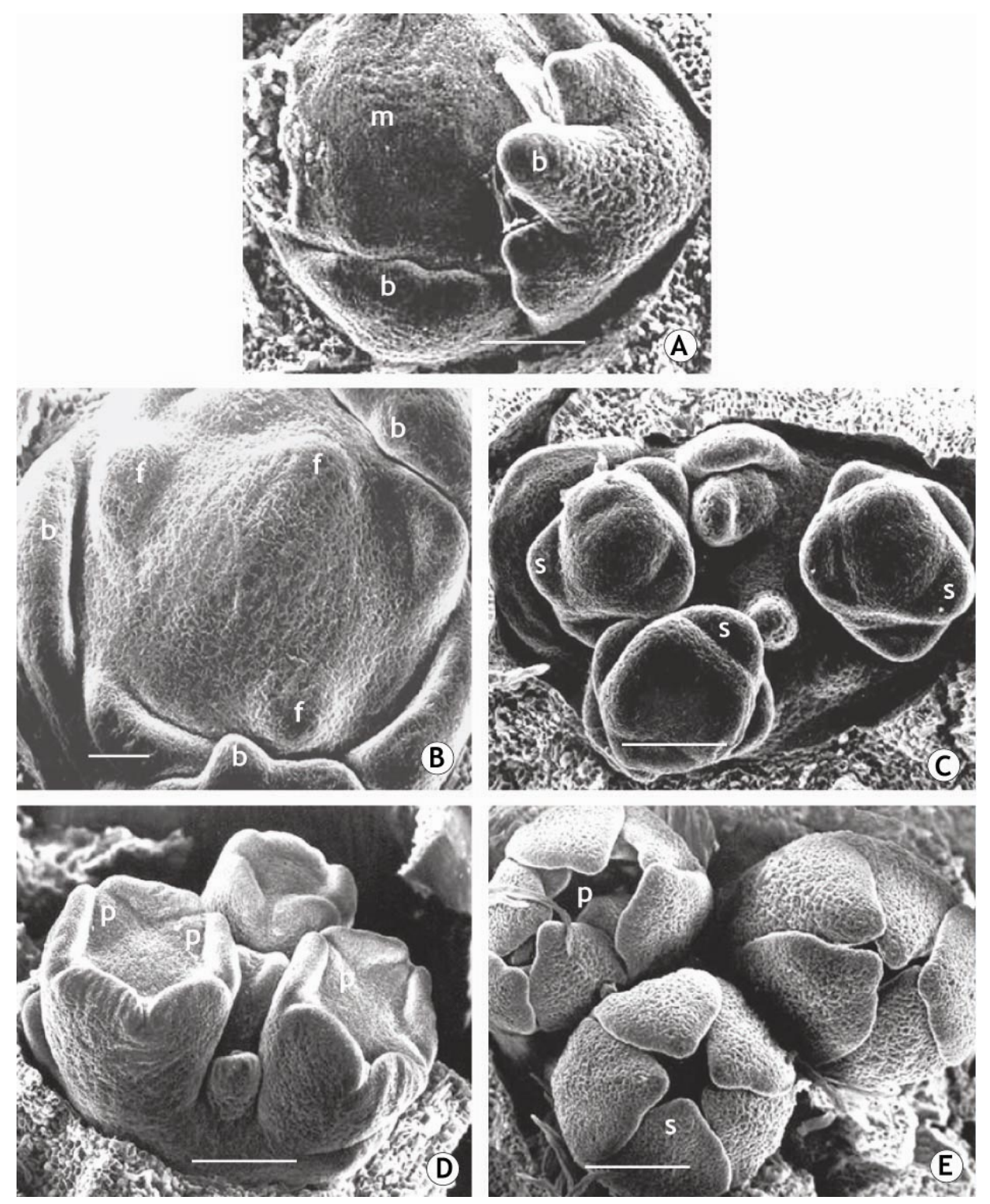

Fig. 1. Cherry buds of '0900 Ziraat' showing developmental changes during flower initiation. A. Initial phase of change from vegetative to reproductive stage, showing rounded meristem (m) and bract (b) primordia; bar $=100 \mu \mathrm{m}$. B. Flower (f) primordia enlarged and rounded; bar $=50 \mu \mathrm{m}$. C. Sepal (s) primordia in pentagonal whorl; bar $=100 \mu \mathrm{m}$. D. Petal $(\mathrm{p})$ primordia differentiate; bar $=100 \mu \mathrm{m}$. E. All floral organs differentiated, including sepal (s), petal (p) stamens and pistil; bar $=100 \mu \mathrm{m}$. 
Table 1. Effect of water stress on the progression of flower bud formation in ' 0900 Ziraat' sweet cherry in 2004.

\begin{tabular}{|c|c|c|c|c|c|c|}
\hline \multirow{2}{*}{$\begin{array}{l}\text { Sampling } \\
\text { date }\end{array}$} & \multirow{2}{*}{$\begin{array}{l}\text { Irrigation } \\
\text { treatments }\end{array}$} & \multicolumn{5}{|c|}{ Flowers (\%) at the stage of differentiation } \\
\hline & & $\begin{array}{c}\text { Flower } \\
\text { primordia }\end{array}$ & $\begin{array}{c}\text { Sepal } \\
\text { primordia }\end{array}$ & $\begin{array}{c}\text { Petal } \\
\text { primordia }\end{array}$ & $\begin{array}{c}\text { Stamen } \\
\text { primordia }\end{array}$ & $\begin{array}{c}\text { Pistil } \\
\text { primordia }\end{array}$ \\
\hline \multirow[t]{3}{*}{ July 21} & $\mathrm{I}_{20}$ & 13.3 & 9.5 & 58.9 & 18.3 & - \\
\hline & $\mathrm{I}_{50}$ & 8.4 & 24.4 & 49.1 & 18.1 & - \\
\hline & $\mathrm{I}_{100}$ & 2.1 & 5.8 & 72.2 & 19.9 & - \\
\hline \multirow[t]{3}{*}{ July 31} & $\mathrm{I}_{20}$ & 10.8 & 29.9 & 59.3 & - & - \\
\hline & $\mathrm{I}_{50}$ & - & 7.5 & 69.4 & 23.1 & - \\
\hline & $\mathrm{I}_{100}$ & - & 3.3 & 46.4 & 50.3 & - \\
\hline \multirow[t]{3}{*}{ August 10} & $\mathrm{I}_{20}$ & 5.4 & 35.4 & 59.2 & - & - \\
\hline & $\mathrm{I}_{50}$ & - & 2.5 & 8.7 & 83.1 & 5.7 \\
\hline & $\mathrm{I}_{100}$ & - & - & 4.4 & 63.9 & 31.7 \\
\hline \multirow[t]{3}{*}{ August 20} & $\mathrm{I}_{20}$ & - & 35.3 & 57.4 & 7.3 & - \\
\hline & $\mathrm{I}_{50}$ & - & - & 8.3 & 82.8 & 8.9 \\
\hline & $\mathrm{I}_{100}$ & - & - & - & 27.8 & 72.2 \\
\hline \multirow[t]{3}{*}{ August 30} & $\mathrm{I}_{20}$ & - & 8.8 & 9.1 & 75.4 & 6.7 \\
\hline & $\mathrm{I}_{50}$ & - & - & - & 42.5 & 57.5 \\
\hline & $\mathrm{I}_{100}$ & - & - & - & 3.7 & 96.3 \\
\hline \multirow[t]{3}{*}{ September 9} & $\mathrm{I}_{20}$ & - & - & 5.2 & 12.1 & 82.7 \\
\hline & $\mathrm{I}_{50}$ & - & - & - & 8.4 & 91.6 \\
\hline & $\mathrm{I}_{100}$ & - & - & - & 2.6 & 97.4 \\
\hline
\end{tabular}

Table 2. Effect of water stress on the progression of flower bud formation in ' 0900 Ziraat' sweet cherry in 2005.

\begin{tabular}{|c|c|c|c|c|c|c|}
\hline \multirow{2}{*}{$\begin{array}{l}\text { Sampling } \\
\text { date }\end{array}$} & \multirow{2}{*}{$\begin{array}{l}\text { Irrigation } \\
\text { treatments }\end{array}$} & \multicolumn{5}{|c|}{ Flowers (\%) at the stage of differentiation } \\
\hline & & $\begin{array}{c}\text { Flower } \\
\text { primordia }\end{array}$ & $\begin{array}{c}\text { Sepal } \\
\text { primordia }\end{array}$ & $\begin{array}{c}\text { Petal } \\
\text { primordia }\end{array}$ & $\begin{array}{c}\text { Stamen } \\
\text { primordia }\end{array}$ & $\begin{array}{c}\text { Pistil } \\
\text { primordia }\end{array}$ \\
\hline \multirow[t]{3}{*}{ July 31} & $\mathrm{I}_{20}$ & 87.6 & 12.4 & - & - & - \\
\hline & $\mathrm{I}_{50}$ & 6.2 & 77.3 & 16.5 & - & - \\
\hline & $\mathrm{I}_{100}$ & - & 70.8 & 24.5 & 4.7 & - \\
\hline \multirow[t]{3}{*}{ August 10} & $\mathrm{I}_{20}$ & 78.3 & 14.2 & 7.5 & - & - \\
\hline & $\mathrm{I}_{50}$ & - & 35.9 & 40.2 & 23.9 & - \\
\hline & $\mathrm{I}_{100}$ & - & 3.7 & 27.5 & 57.4 & 11.4 \\
\hline \multirow[t]{3}{*}{ August 20} & $\mathrm{I}_{20}$ & 7.8 & 15.8 & 62.9 & 13.5 & - \\
\hline & $\mathrm{I}_{50}$ & - & - & 8.6 & 73.1 & 18.3 \\
\hline & $\mathrm{I}_{100}$ & - & - & 2.4 & 54.7 & 42.9 \\
\hline \multirow[t]{3}{*}{ August 30} & $\mathrm{I}_{20}$ & - & 18.5 & 18.6 & 60.3 & 2.6 \\
\hline & $I_{50}$ & - & - & 7.2 & 58.4 & 34.4 \\
\hline & $\mathrm{I}_{100}$ & - & - & 4.2 & 32.9 & 62.9 \\
\hline \multirow[t]{3}{*}{ September 9} & $\mathrm{I}_{20}$ & - & - & 13.8 & 57.5 & 28.7 \\
\hline & $\mathrm{I}_{50}$ & - & - & - & 12.1 & 87.9 \\
\hline & $\mathrm{I}_{100}$ & - & - & - & 2.5 & 97.5 \\
\hline \multirow{3}{*}{ September 19} & $\mathrm{I}_{20}$ & - & - & 4.8 & 19.8 & 75.4 \\
\hline & $\mathrm{I}_{50}$ & - & - & -- & 3.2 & 96.8 \\
\hline & $\mathrm{I}_{100}$ & - & - & - & - & 100 \\
\hline
\end{tabular}


Results obtained during this investigation confirmed that optimum irrigation accelerated flower differentiation considerably. In mid-August, sepal, petal, stamen and pistil primordia formed in the buds under optimum irrigation. However, under severe water stress, most of the buds were still at the stage of sepal and petal differentiation. These facts suggested that decreasing irrigation slowed the progression of flower differentiation.

\section{References}

Alburquerque, N., L. Burgos and J. Egea. 2003. Apricot flower bud development and abscission related to chilling, irrigation and type of shoots. Scientia Horticulturae 98: 265-276.

Engin, H. 2006. Scanning electron microscopy of floral initiation and developmental stages in 'Glohaven' peach under water deficit. Bangladesh J. Bot. 35(2):163-168.

Faust, M. 1989. Physiology of temperate zone fruit trees. Wiley, New York.

Guimond, M.C., P.K. Andrews and G.A. Lang, 1998. Scanning electron microscopy of floral initiation in sweet cherry. J. Amer. Soc. Hort. Sci. 123: 509-512.

Kappel, F., M. Bouthillier and L. Veto. 1990. A study of flower bud differentiation in sweet cherry by scanning electron microscope. Hort. Sci. 25: 1106.

McLaughlin, J.M. and D.W. Greene. 1991. Fruit and hormones influence flowering of apple. I. Effect of cultivar. J. Amer. Soc. Hort. Sci. 116: 446-449.

Westwood, M.N. 1993. Temperate-zone pomology-physiology and culture. (3rd edn). Timber Press, Portland, Ore., USA.

(Manuscript received on 15 May, 2007; revised on 21 July, 2007) 